\title{
IN VIVO CORROSION OF COBALT-CHROMIUM AND TITANIUM WEAR PARTICLES
}

\author{
B. F. SHAHGALDI, F. W. HEATLEY, A. DEWAR, B. CORRIN
}

From St Thomas' Hospital and the Royal Brompton and National Heart Hospital, London, England

Tissue reaction to wear particles from metal implants may play a major role in the aseptic loosening of implants. We used electron microprobe elemental analysis to determine the chemical composition of wear particles embedded in the soft tissues around hip and knee implants from 11 patients at revision surgery for aseptic loosening. The implants were made of cobalt-chromium-molybdenum alloy or titaniumaluminium-vanadium alloy.

Histological examination showed a widespread giant-cell reaction to the particles. Elemental analysis showed that the chemical composition of the particles was different from that of the implanted alloys: cobalt and titanium were reduced, often down to zero, whereas chromium and aluminium persisted.

Our findings indicate that corrosion is continually changing the shape, size and chemical composition of the implanted alloy. This may alter the biochemical environment of the tissue surrounding an implant to favour bone resorption.

J Bone Joint Surg [Br] 1995;77-B:962-6.

Received 9 March 1995; Accepted after revision 30 May 1995

B. F. Shahgaldi, PhD, Research Scientist/Bioengineer

F. W. Heatley, FRCS, Reader and Honorary Consultant in Orthopaedic Surgery

Orthopaedic Academic Unit (UMDS), The Rayne Institute, St Thomas' Hospital, Lambeth Palace Road, London SE1 7EH, UK.

A. Dewar, MIBiol, Electron Microscopist

B. Corrin, MD, FRCPath, Professor of Thoracic Pathology

National Heart and Lung Institute, Royal Brompton and National Heart Hospital, Fulham Road, London SW3 6HP, UK.

Correspondence should be sent to Dr B. F. Shahgaldi.

C1995 British Editorial Society of Bone and Joint Surgery

0301-620X/95/61095 $\$ 2.00$
Aseptic loosening of orthopaedic implants is frequently attributed to tissue reaction to wear debris (Willert and Semlitsch 1977; Goldring et al 1983; Agins et al 1988; Lombardi et al 1989; Galante et al 1991; Haynes et al 1993). Although the tissue response to metal wear particles has been well described the chemical composition of the particles has seldom been studied (Vernon-Roberts and Freeman 1977; Maloney et al 1983; Howie and VernonRoberts 1988; Howie 1990; Lee et al 1992; Haynes et al 1993; Jiranek et al 1993). It is often assumed that wear particles maintain the volume and the composition of the implanted alloy. Chemical analysis of tissues containing metal debris has usually used techniques such as atomic absorption spectroscopy or mass spectrometry which reveal only the bulk composition of particles (Woodman et al 1984; Agins et al 1988; Sunderman et al 1989; Case et al 1994). Techniques capable of determining individual particle chemistry, such as electron microprobe elemental analysis, have seldom been employed (Agins et al 1988; Case et al 1994; Shanbhag et al 1994).

There is indirect evidence, however, that metal particles undergo chemical changes in vivo. Swanson, Freeman and Heath (1973), after laboratory wear studies, used atomic absorption spectroscopy to detect ionic cobalt in the lubrication medium and suggested that wear particles may undergo corrosion in vivo. Systemic elevation of trace metal in patients with failed implants also indicates that particles undergo corrosion in vivo (Sunderman et al 1989).

Corrosion alters the shape, size and chemical composition which influence the type and extent of tissue response. Individual metals liberated from the alloy undergo different forms of oxidation or bind with different proteins (Connors, Skilleter and Brown 1990).

We report the chemical composition of wear particles embedded in soft tissue around failed hip and knee implants. Histological examination and polarised light and electron microscopy were used to locate metal wear particles and energy-dispersive electron microprobe analysis (EDX) was used for their elemental analysis.

\section{MATERIALS AND METHODS}

Soft tissues were obtained from failed hip and knee implants from 11 patients undergoing revision surgery for aseptic loosening. Two specimens were from hip implants 


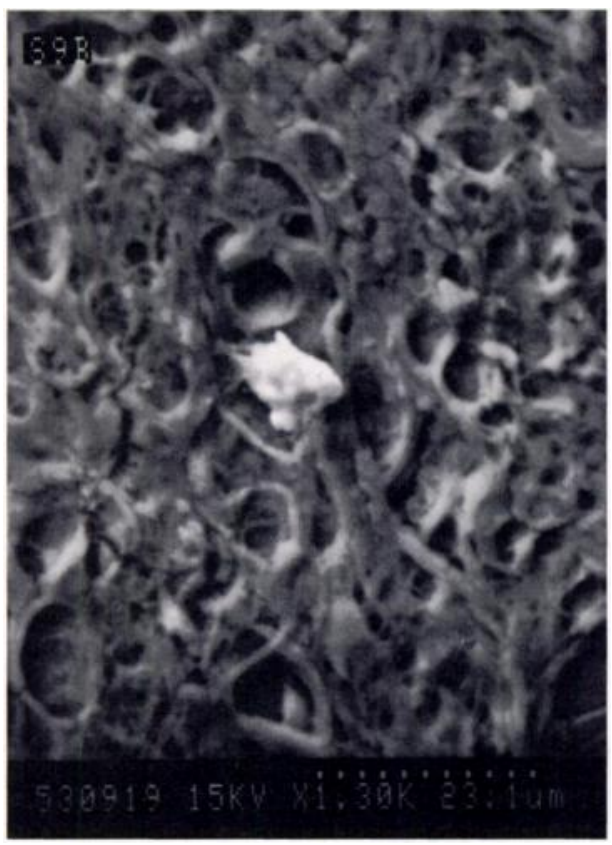

Fig. 1a

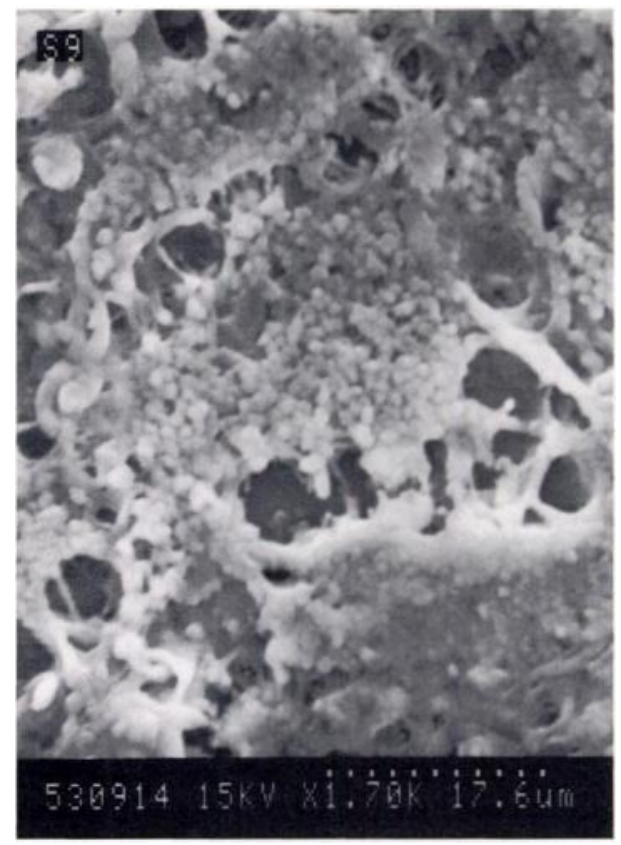

Fig. Ib

Scanning electron micrographs showing metal deposits in soft tissue. Figure la - A newly worn particle $(\times 650)$. Figure $1 \mathrm{~b}-$ An older particle (granulation structure: $\times 850$ ).

with cobalt-chromium-molybdenum alloy femoral components and cups: these had been in place for 25 and 19 years. One specimen was from a hip implant with a cobaltchromium-molybdenum femoral component and a polyethylene cup which had been in place for seven years. Two specimens were from knee implants with cobalt-chromiummolybdenum alloy femoral components and polyethylene tibial inserts backed with the same alloy: these had been in place for two and three years. Six specimens were from hips with titanium-aluminium-vanadium femoral components and polyethylene cups: they had been in place for three to nine years. All the implants had been cemented in position.

Specimens for histology and polarised light microscopy were processed by routine methods and paraffin sections were stained with haematoxylin and eosin. For scanning electron microscopy $10 \mu \mathrm{m}$ thick paraffin sections were mounted on perspex blocks, dewaxed, coated with carbon and examined at an acceleration voltage of $15 \mathrm{kV}$. The secondary electron mode was used to examine the morphology of the particles. The backscatter electron mode was used for localisation and the X-ray analyser for EDX of particles. The specimens were of uniform thickness and it was ensured that they were flat. Specimen tilt $\left(45^{\circ}\right)$, working distance $(15 \mathrm{~mm})$ and $\mathrm{X}$-ray detector position were constant. In all cases, X-ray spectra were obtained for 200 seconds. For transmission electron microscopy the specimens were fixed in $2 \%$ neutral $(\mathrm{pH} 7)$ glutaraldehyde and embedded in resin. Ultrathin sections were examined by transmission electron microscopy with scanning transmis- sion (STEM) and X-ray analysis facilities. Heavy metal stains routinely used in transmission electron microscopy were omitted.

\section{RESULTS}

The specimens were grey to black. Those contaminated with titanium-aluminium-vanadium alloy particles were more heavily stained than those contaminated with cobaltchromium alloy particles. Metal and polyethylene wear particles were identified microscopically using polarised light and both were generally engulfed by foreign-body giant cells. Scanning (Fig. 1) and transmission (Fig. 2) electron microscopy showed that wear particles of cobaltchromium alloy were spherical and ranged from submicron to $4 \mu \mathrm{m}$ in diameter whereas those of titanium alloy were spherical or rod-like, and ranged from submicron to $9 \mu \mathrm{m}$ in length.

A typical alloy contains about $57 \%$ cobalt. $37 \%$ chromium and less than $5 \%$ molybdenum with traces of impurities, but EDX showed that the wear particles contained varying quantities of cobalt and chromium. The proportion of cobalt ranged from that close to the implant alloy down to zero (Figs 3 to 5). This pattern was found to be independent of implantation time and wear particles with greatly reduced cobalt were regarded as having been in the tissue for longer than those with proportions similar to the implant alloy. Cobalt was not detected in isolation. In contrast, chromium was regularly seen in isolation in particles that were both free and within cells (Figs 2 and 6). 


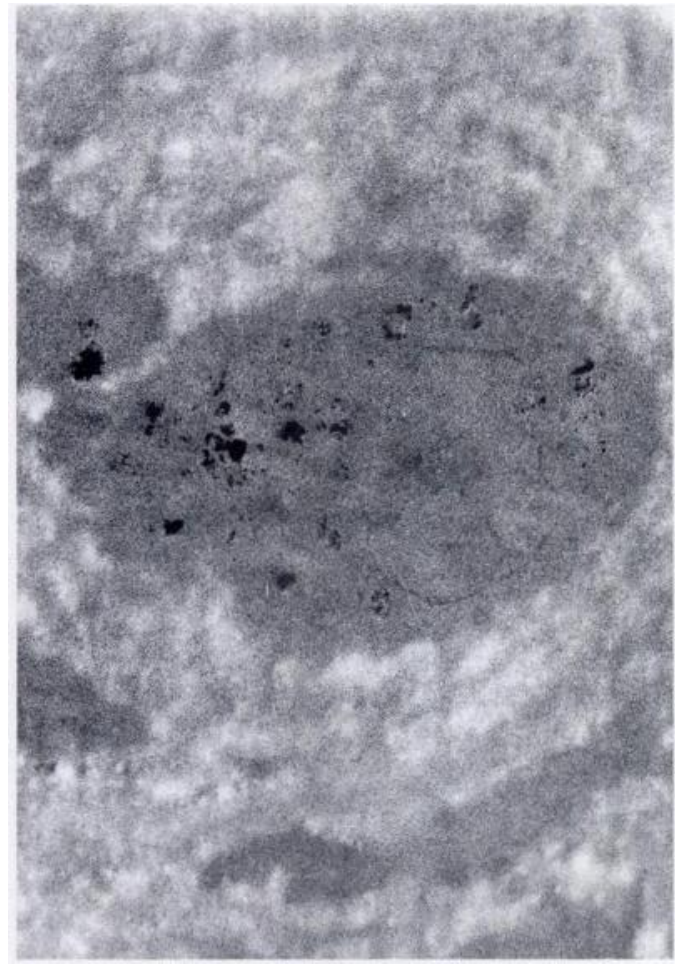

Fig. 2

Transmission electron micrograph showing intercellular metal deposits $(\times 2700$, section not stained $)$.

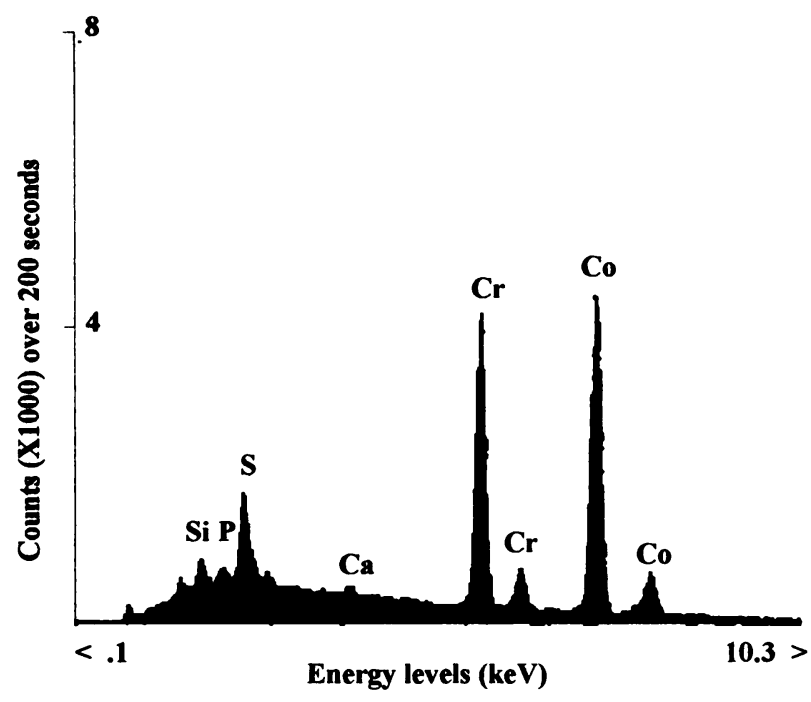

Fig. 3

$\mathrm{X}$-ray spectrum of a newly worn particle, as in Figure 1a, showing the proportions of cobalt and chromium close to those of the implant alloy.

We were not able to detect molybdenum because its peaks coincide with those of sulphur, which as expected was always present in these biological specimens. With the $15 \mathrm{kV}$ excitation energy used, the $\mathrm{L}$ lines of molybdenum (Mo $\mathrm{La}=2.29, \mathrm{Lb}=0.54$ ) coincide with the $\mathrm{K}$ lines of sulphur $(\mathrm{S} \mathrm{Ka}=2.31 ; \mathrm{Kb}=0.54)$.

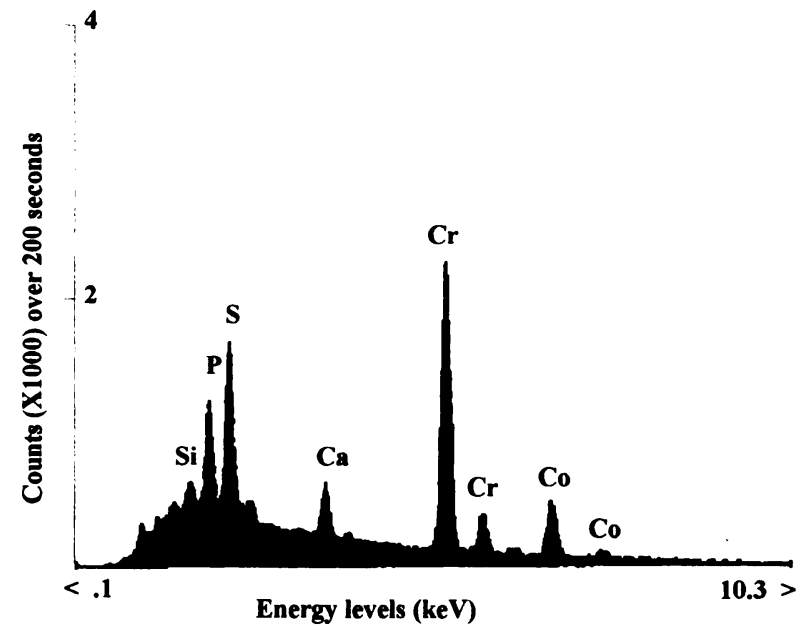

Fig. 4

$\mathrm{X}$-ray spectrum showing reduced cobalt in an older wear particle.

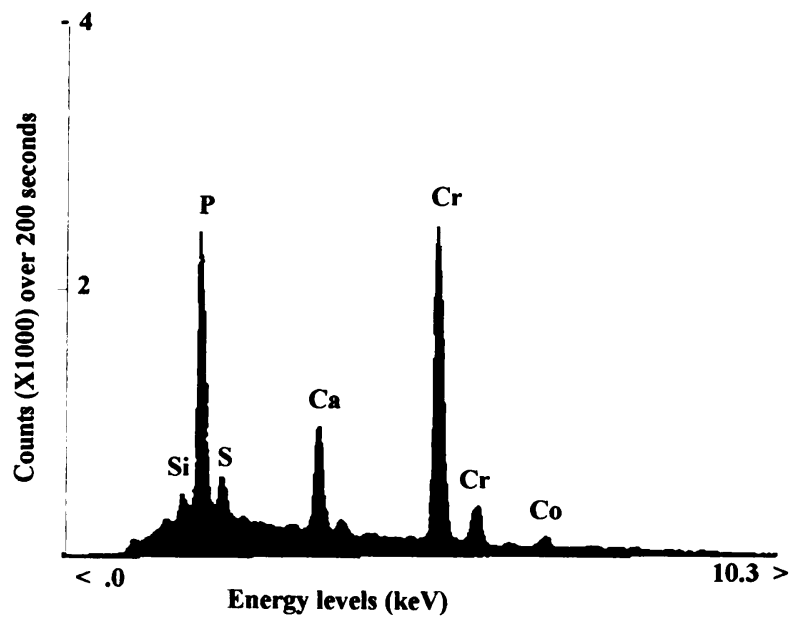

Fig. 5

$\mathrm{X}$-ray spectrum showing markedly reduced cobalt in a considerably older wear particle, as in Figure $1 \mathrm{~b}$.

A similar pattern was found in specimens containing titanium-aluminium-vanadium alloy wear particles. The amount of titanium varied from close to that of the implant alloy (about $90 \%$ of total alloy) to just detectable. In contrast, the aluminium peak was often close to that of the implant alloy or greater (Figs 7 to 9). In general, titanium and aluminium were not detected alone. The titanium alloys also contain vanadium ( $4 \%$ or less) but vanadium is difficult to detect because its energy peaks overlap those of titanium ( $\mathrm{Ti} \mathrm{Ka}=4.51 ; \quad \mathrm{Kb}=0.27 ; \quad \mathrm{V} \quad \mathrm{Ka}=4.95$; $\mathrm{Kb}=0.25$ ).

All the elements present could be accounted for. They were either all constituents of the implant alloy, bone 


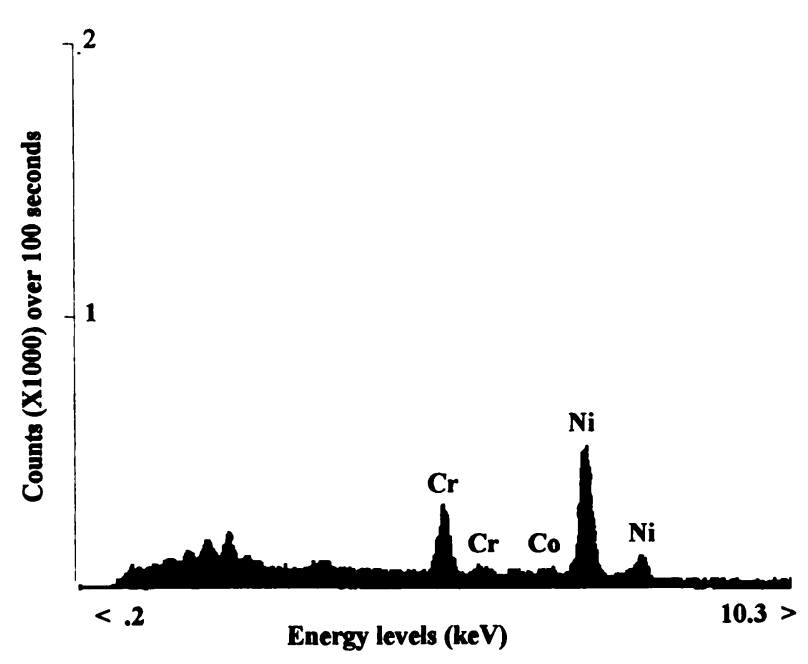

Fig. 6

$\mathrm{X}$-ray spectrum showing that the metal deposits as shown in Figure 2, are compounds of chromium alone, the nickel peak being from the specimen grid.

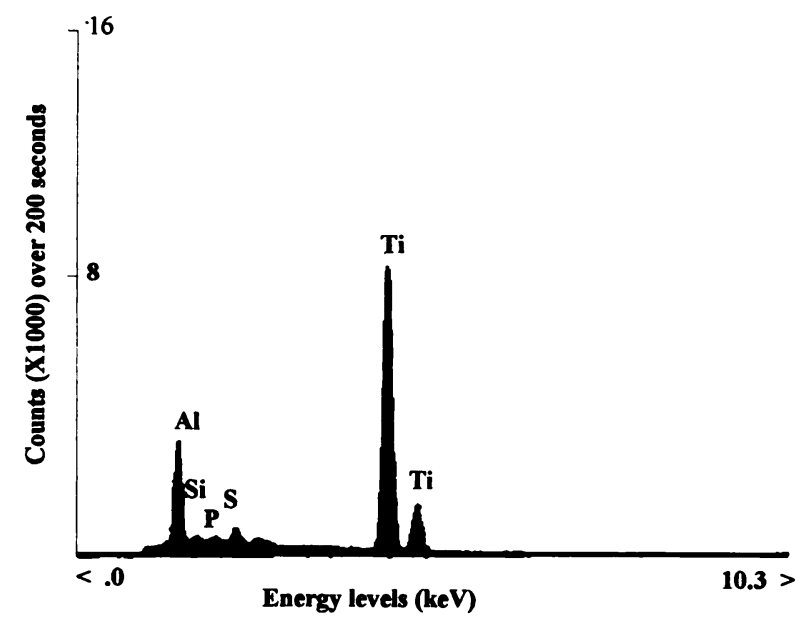

Fig. 8

$\mathrm{X}$-ray spectrum showing less titanium in an older wear particle than that seen in Figure 7.

cement (barium and zirconium), or tissue (calcium and phosphorus) or were likely to have been introduced from stainless-steel surgical instruments (iron, nickel and chromium).

\section{DISCUSSION}

The corrosion of wear particles in vivo has important clinical implications. It changes the shape and size of the particles which affects the tissue reaction thus favouring bone resorption (Maloney et al 1983; Howie 1990; Lee et al 1992; Shanbhag et al 1994).

Cobalt and titanium are more soluble and are therefore

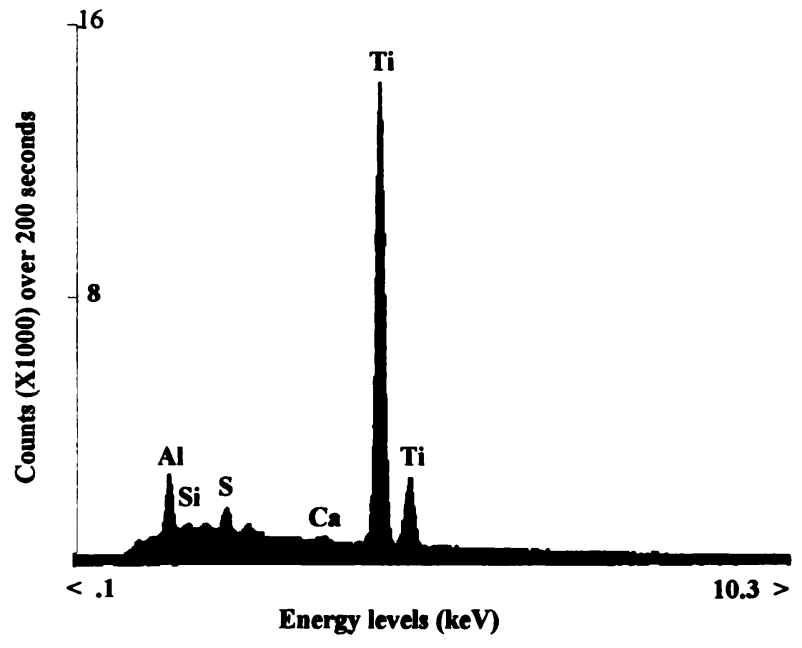

Fig. 7

$\mathrm{X}$-ray spectrum showing the proportions of aluminium and titanium in a newly worn particle.

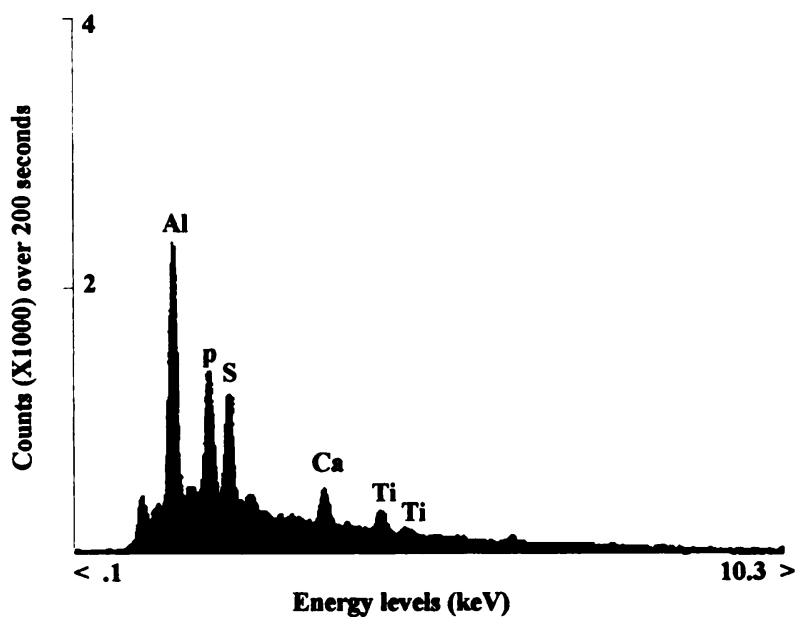

Fig. 9

X-ray spectrum showing markedly reduced titanium in a considerably older wear particle.

removed faster than aluminium and chromium, which persist. Case et al (1994) found nearly five times more cobalt but only twice as much chromium in the draining lymph nodes than in the synovium of patients who had failed cobalt-chromium implants. Agins et al (1988) concluded that the wear particles have the same elemental composition as the implant alloy but their results clearly showed that the chemical composition of titaniumaluminium-vanadium wear particles changed in vivo. Different elements and different compounds of the same element evoke different tissue reactions (Rae 1981; Maloney et al 1983). Haynes et al (1993) attributed toxicity of cobalt to its high solubility and showed that cobalt- 
chromium alloy particles are more toxic than those from titanium alloys.

We thank Dr Alice Warley, Physiology Department, UMDS, St Thomas' Hospital for her help with the STEM analysis and Mr B. L. Hinves, FRCS, Conquest Hospital, Hastings, for the supply of specimens and his encouragement.

No benefits in any form have been received or will be received from a commercial party related directly or indirectly to the subject of this article.

\section{REFERENCES}

Agins HJ, Alcock NW, Bansal M, et al. Metallic wear in failed titaniumalloy total hip replacements: a histological and quantitative analysis. $J$ Bone Joint Surg [Am] 1988;70-A:347-56.

Case CP, Langkamer VG, James C, et al. Widespread dissemination of metal debris from implants. J Bone Joint Surg [Br] 1994;76-B:701-12.

Connors TA, Skilleter DN, Brown RC. Occupational poisons. In: Cohen RD, Lewis B, Alberti KGMM, Denman AM, eds. The metabolic and molecular basis of acquired disease. Vol. 1. London, etc: Bailliére Tindall, 1990:443-65.

Galante JO, Lemons J, Spector M, Wilson PD Jr, Wright TM. The biologic effects of implant materials. J Orthop Res 1991;9:760-75.

Goldring SR, Schiller AL, Roelke M, et al. The synovial-like membrane at the bone-cement interface in loose total hip replacements and its proposed role in bone lysis. $J$ Bone Joint Surg [Am] 1983;65-A:57584.

Haynes DR, Rogers SD, Hay S, et al. The differences in toxicity and release of bone-resorbing mediators induced by titanium and cobaltchromium-alloy wear particles. J Bone Joint Surg [Am] 1993; 75-A:825-34.

Howie DW. Tissue response in relation to type of wear particles around failed hip arthroplasties. J Arthroplasty 1990;5:337-48.

Howie DW, Vernon-Roberts B. Synovial macrophage response to aluminium oxide ceramic and cobalt-chrome alloy wear particles in rats. Biomaterials 1988;9:442-8.
Jiranek WA, Machado M, Jasty M, et al. Production of cytokines around loosened cemented acetabular components: analysis with immunohistochemical techniques and in situ hybridization. $J$ Bone Joint Surg [Am] 1993;75-A:863-79.

Lee J-M, Salvati EA, Betts F, et al. Size of metallic and polyethylene debris particles in failed cemented total hip replacements. J Bone Joint Surg [Br] 1992;74-B:380-4.

Lombardi AV, Mallory TH, Vaughan BK, Drouillard P. Aseptic loosening in total hip arthroplasty secondary to osteolysis induced by wear debris from titanium-alloy modular femoral heads. J Bone Joint Surg [Am] 1989;71-A:1337-42.

Maloney WJ, Smith RL, Castro F, Schurman DJ. Fibroblast response to metallic debris in vitro: enzyme induction, cell proliferation and toxicity. J Bone Joint Surg [Am] 1993;75-A:835-44.

Rae T. The toxicity of metals used in orthopaedic prostheses: an experimental study using cultured human synovial fibroblasts. J Bone Joint Surg [Br] 1981;63-B:435-40.

Shanbhag AS, Jacobs JJ, Glant TT, et al. Composition and morphology of wear debris in failed uncemented total hip replacement. J Bone Joint Surg [Br] 1994;76-B:60-7.

Sunderman FW Jr, Hopfer SM, Swift T, et al. Cobalt, chromium and nickel concentrations in body fluids of patients with porous-coated knee or hip prostheses. J Orthop Res 1989;7:307-15.

Swanson SAV, Freeman MAR, Heath JC. Laboratory tests on total joint replacement prostheses. J Bone Joint Surg [Br] 1973;55-B:759-73.

Vernon-Roberts D, Freeman MAR. The tissue response to total joint replacement prostheses. In: Swanson SAV, Freeman MAR, eds. The scientific basis of joint replacement. Tunbridge Wells: Pitman Medical, 1977:86-129.

Willert HG, Semlitsch M. Reactions of the articular capsule to wear products of artificial joint prostheses. J Biomed Mater Res 1977; 11:157-64.

Woodman JL, Jacobs JJ, Galante JO, Urban RM. Metal ion release from titanium-based prosthetic segmental replacements of long bones in baboons: a long-term study. J Orthop Res 1984;1:421-30. 